DOI: 10.20472/IAC.2019.048.034

JOÃO LOPES

ISEG/UECE - University of Lisbon, Portugal

\title{
LABOUR PRODUCTIVITY, WAGES AND FUNCTIONAL DISTRIBUTION OF INCOME IN PORTUGAL: A SECTORAL APPROACH
}

\begin{abstract}
:
This paper studies the evolution of the functional distribution of income in Portugal. The changes in the labour share of income result from two important trends, namely the evolutions of labour productivity and the average wage. And the global trends of these variables at the national level are a weighted average of the corresponding trends in the different sectors or industries, each one with its own peculiarities and deserving an attentive analysis. All these trends are quantified and explained, using several databases covering the Portuguese case in a long run period, 1953-2017 (EU- KLEMS, OECD- STAN, INE-Contas Nacionais; Banco de Portugal-Séries Longas; Ministério do Trabalho-Quadros de Pessoal). Particular attention is given to the Mixed Income problem, adjusting the Labour Share with the (imputed) labour component of the self-employed workers' income. The consequences of wage inequalities are also taken into account, calculating the (adjusted) labour share of the so-called "tipical workers", those of the $(99 \%, 95 \%$ or $90 \%)$ bottom scale of the wage distribution. At the sectoral level, by means of a shift share analysis, the absolute change in the labour share is divided into two components, the "within industries" effect (changes in the labour share of each sector) and the "between industries" effect (changes in the gross value added relative weight of each sector).
\end{abstract}

\section{Keywords:}

Labour productivity; Average Wages; Factor income distribution; Wage inequalities; Industries; Portugal

JEL Classification: D33 